\title{
From a Habit to a Husband: Representation of the Intersection between Religion and Masculinities in John Ruganda's Play, The Burdens (1972)
}

\section{Danson Sylvester Kahyana ${ }^{1}$}

\begin{abstract}
${ }^{1}$ SHORT BIO
Danson Sylvester Kahyana is a Senior Lecturer in the Literature Department at Makerere University and a research Associate in the English Department at Stellenbosch University.
\end{abstract}

\section{INSTITUTIONAL AFFILIATION}

Makerere University, Uganda/Stellenbosch University, South Africa

dkdan76@gmail.com.

ORCID

https://orcid.org/0000-0001-7560-451X

\begin{abstract}
This paper examines how John Ruganda represents the intersection between religion and masculinities in his play, The Burdens (1972), which imagines an ex-Catholic nun marrying and bringing up a family. It argues that literary texts are an important avenue through which the intersection between religion and gender can be explored, leading to a rich harvest of nuanced insights. Data is collected through a close reading of the play under analysis, within the socio-political context in which it was written and produced, that is, the politically turbulent decade following Uganda's flag independence in 1962, characterised - among others - by events like the abolition of kingdoms by the Prime Minister, Milton Obote, and his ouster in a military coup by his army commander, General Idi Amin, on 25 January, 1971. The analysis of the text is guided by insights drawn from selected scholars of masculinities featured in Helen Nabasuta Mugambi and Tuzyline Jita Allan's edited volume, entitled Masculinities in African and Cultural Texts (2010).
\end{abstract}

KEYWORDS

Sexuality, masculinity, the Catholic Church, poverty

\section{Introduction}

John Ruganda (1941-2007) was Uganda's best known and greatest playwright, with six published plays: The Burdens (1972), Black Mamba (1973), Covenant with Death (1973), The Floods (1980), Music without Tears (1982, republished in 2001 as Shreds of Tenderness) and Echoes of Silence (1986). Virtually all his works, as Francis Davis Imbuga highlights, are "studied in universities in East and Central Africa," yet there is quite

1 I would like to acknowledge the financial assistance provided by the Urban Connection in African Popular Imaginaries (UCAPI) project at Rhodes University 
From a Habit to a Husband: Representation of the Intersection between Religion and Masculinities in John Ruganda's Play, The Burdens (1972)

little scholarship on him in general, and on The Burdens in particular. ${ }^{2}$ This paper provides a detailed analysis of how Ruganda depicts religion and masculinities in his first published play, which features an ex-Catholic nun as one of its major characters. In his work, Ruganda "dramatizes the African man's [sic] plight and struggle for survival in a hostile social, economic and political environment in which he is alienated to the position of a passive observer by a minority class of cut-throat businessmen and political opportunists." ${ }^{3}$ In all the plays mentioned above, the protagonists experience a sense of entrapment and helplessness as the world they live in crumbles.

The Burdens tells the story of Wamala who was once a minister in a newly independent state, but who fell into disgrace and squalor upon being fired and detained for two years, allegedly for attempting to overthrow the government he was serving, at the instigation of American Yankees who told him that he would make a better boss. When he is released from prison, he fails to get a job because he is a marked man with whom nobody wants to associate. In frustration, he turns to the bottle and becomes a hopeless drunk and helpless destitute in a faeces-infested slum with prowling robbers. His relationship with his wife, Tinka, becomes strained, for not only is he unable to provide for her and their two children (Kaija and Nyakake), but he is also violent to her, as evidenced by the many fights they have, one of which ends fatally when she kills him. Peter Nazareth describes the play as being "tightly constructed [for] it has only four characters and is in a very spare and taut language," ${ }^{4}$ which is why Simon Gikandi and Evan Mwangi link it, like Ruganda's other dramatic works, "with the tradition of minimalist theatre, associated with writers such as Athol Fugard and Wole Soyinka, rather than the grandiose, ritualistic projects of many of his East African contemporaries, most notably Ebrahim Hussein and Ngugi wa Thiong'0."5

2 Francis Davis Imbuga, "An Introduction to John Ruganda, the Playwright," in Uganda: The Cultural Landscape, ed. Eckhard Breitinger (Kampala: Fountain Publishers, 2000), 250.

3 Imbuga, "An Introduction", 251-252.

4 Peter, Nazareth, "The Social Responsibility of the East African Writer," Callaloo 8/10 (1980): 95.

5 Simon Gikandi and Evan Mwangi, The Columbia Guide to East African Literature in English Since 1945 (New York: Columbia University Press, 2007), 155. 
Gikandi and Mwangi describe the play as "one of the most devastating portraits of postcolonial failure," with the politics of colonialism being "refracted through the main character's failure as a father in the most mundane of tasks, such as providing a bed for his son or taking his daughter to a hospital." ${ }^{6}$ There are several other indicators of the play's investment in politics, for instance the failed coup allegedly carried out by Wamala, his identity as an ex-minister who married a prominent chief's daughter for political expediency, and - among others - the reference to a firing squad, which Chris J. C. Wasike rightly reads as alluding "to the ruthless death squads that ran riot during Amin's regime."7

In this paper, I investigate how Ruganda represents the intersection between religion and masculinities in The Burdens. This focus on masculinities is informed by Dorothea Schulz and Marloes Janson's observation that "masculinity studies still suffer from the tendency to theorize masculinity by drawing on empirical data from Europe, North America, and Australia, while paying little attention to the variety of men's practices and subjectivities in African societies." ${ }^{8}$ By focusing on an East African play, I hope to shed some light on the way a prominent writer from the region imagines masculinities in one of his works. The identity of a major character in the play, Tinka, as an ex-Catholic nun, is central to the analysis I offer, for it informs, to a large extent, the audience's shock at what befalls her and her husband, as we delve deeper into the tragedy. The paper also comments on the suitability of drama as a medium through which writers reflect on pertinent societal issues.

\section{Performing Political Masculinity in the Postcolony: Wamala's Humiliation of the Catholic Church}

Tanure Ojaide defines masculinity as "a conglomerate of virtues and characteristics built around the traditional expectations of being a man and the glorification of virile values" - virtues and characteristics which are "not only integral parts of the culture but are also seen by the people as

$6 \quad$ Gikandi and Mwangi, The Columbia Guide, 156.

7 Chris J. C. Wasike, "Feminization of the Ugandan nation in John Ruganda's The Floods, The Burdens and Black Mamba," Postcolonial Text 5, no.3 (2009): 5-6.

8 Dorothea Schulz and Marloes Janson, "Introduction: Religion and Masculinities in Africa," Journal of Religion in Africa 46, no.2/3 (2016): 122. 
From a Habit to a Husband: Representation of the Intersection between Religion and Masculinities in John Ruganda's Play, The Burdens (1972)

meeting established rules of behaviour/conduct and the action of men." 9 This implies that masculinity is contextual in the sense that what it means to be a man in one society might differ from what it means in another. To put it differently, masculinity lies in the domain of what Judith Butler famously called 'gender performativity' - a concept that captures the view, among others, that "what we take to be an internal essence of gender is manufactured through a sustained set of acts, posited through the gendered stylization of the body." 10 If we accept Sara Salih's view that this formulation by Butler is informed by Simone de Beauvoir's famous insight that "[o]ne is not born, but rather becomes, a woman," we can infer that as far as masculinity is concerned, one is not born a man, but becomes one in a specific cultural setting. ${ }^{11}$

The question of what it means to be a man is central to understanding what happens in The Burdens. For instance, to appreciate the privileged position Wamala occupied and the enormous power he wielded before he descended into political insignificance and economic destitution, we need to look at a remarkable passage in the play:

TINKA: The day you held me when the Union Jack was lowered. Do you remember?

WAMALA: (reminiscent) Hand-in-hand among the independence crowds, on to the decorated rostrum. We were big pots then.

TINKA: Shopping at the Supermarket over the phone.

WAMALA: Business deals done at the Inter-Continental.

TINKA: The hairdresser coming home.

9 Tanure Ojaide, "Deploying Masculinity in African Oral Poetic Performance: The Man in Udje," in Masculinities in African Literary and Cultural Texts, eds. Helen Nabasuta Mugambi and Tuzyline Jita Allan (Oxfordshire: Ayebia Clarke Publishing Limited, 2010), 66.

10 Judith Butler, Gender Trouble: Feminism and the Subversion of Identity (London and New York: Routledge, 1999), xv.

11 Sara Salih, Judith Butler (London and New York: Routledge, 2002), 10. 
WAMALA: Bank managers in my study.

TINKA: An insidious upsurge of relatives and friends. ${ }^{12}$

Here, Wamala is portrayed as a man of status - a national politician who witnesses the ushering in of his country's independence. He is a rich man who can shop over the phone and meet bank managers in his study, instead of him going to their offices. It is this power - both economic and political - that he uses to settle his scores with the Catholic Church. For instance, he sleeps with Tinka, a Catholic nun, without feeling any sense of remorse at what he is doing. The first time he does it, he is surprised to find that she is not a "virgin Mary," despite the fact that she had become a nun at sixteen. He accuses Tinka of hypocrisy, but the playwright treats the matter with sensitivity by offering her the opportunity to defend herself against the accusation, in describing the circumstances under which she lost her virginity at fifteen: Sam told her that it would make her forget the sight of her mother "dying in grandmother's hands." 13 I read this as Ruganda's subtle way of challenging the Church to take more interest in sex education programmes, so that people like Sam do not take advantage of girls in distress like Tinka.

While Tinka quits the convent to marry Wamala out of love, it transpires that for him this is not the case. Rather, he seduces her out of curiosity about "[t]he pleasures behind the habit." ${ }^{14}$ More sinisterly, however, he does it as a way of hitting out at his enemy, the Catholic Church, whose priests he accuses of "preaching hatred in pulpits" 15 and "[r]allying nuns, fellow priests and faithfuls against me. Branding our Party communist communists who would rape the nuns and turn the churches into casinos." 16 He relishes what he did: "Boy, I gave them [the priests] what they deserved. Their most trusted nun, the only daughter of an eminent

\footnotetext{
12 John Ruganda, The Burdens (Nairobi: Oxford University Press, 1972), 41-42.

13 Ruganda, The Burdens, 39.

14 Ruganda, The Burdens, 38.

15 Ruganda, The Burdens, 39.

16 Ruganda, The Burdens, 40.
} 
From a Habit to a Husband: Representation of the Intersection between Religion and Masculinities in John Ruganda's Play, The Burdens (1972)

Catholic chief. Ha ha, it was a political masterpiece. And in your spiritual dusk, my dear, was my political dawn and their defeat." ${ }^{17}$

By turning Tinka into a weapon with which to fight the Catholic Church in his quest for national political office, Wamala empties her of her humanity. In this regard, Ruganda depicts him as an insensitive character who neither cares about her feelings, desires and interests nor worries about the stigma she might suffer as a result of leaving the habit for a husband. Unfortunately, she had no idea of his intention, for even when she heard people say that her impending marriage to him was politically motivated, she dismissed this talk as frivolous gossip and went ahead and tied the knot with him.

For Wamala, having sexual intercourse with a nun is aimed at challenging the moral hegemony of the Church by demonstrating that the religious people - both men and women - are not as holy or as pure as they claim to be. Similarly, he is critical of the Catholic sacrament of confession/reconciliation because to him, it is presided over by paedophiles - male priests who press "their chests on young boys." 18 In these two respects, the play can be said to be iconoclastic, particularly in the first one, if we consider the fact that the Catholic Church considers a nun to be "a bride of Christ", making Wamala's act of fornicating with, and later marrying, Tinka, an affront on the Church. ${ }^{19}$

This affront should be understood in the context of Church-state relations in both colonial and post-colonial Uganda, with the Anglican (sometimes called Protestant) Church receiving more favour from the political leadership of the protectorate than the Catholic Church. In the colonial period, "Protestant [Anglican] missionaries became the missionaries closest to the various centres of power in Uganda whilst the Catholics tended to remain on its periphery." 20 Bengt Sundkler and Christopher

\footnotetext{
17 Ruganda, The Burdens, 40-41.

18 Ruganda, The Burdens, 40.

19 Helen Hills, "The Veiled Body: Within the Folds of Early Modern Neapolitan Convent Architecture," Oxford Art Journal 27, no.3 (2004): 278.

20 Akiiki B Mujaju, "The Political Crisis of Church Institutions in Uganda," African Affairs 75, no.298 (1976): 68.
} 
The African Journal of Gender and Religion Vol. 26 No 1 (2020)

Steed confirm this by observing that the head of the Anglican Church was, "according to Ugandan protocol, placed in the third place, after governor and kabaka [King of Buganda Kingdom]." ${ }^{11}$ When colonialism ended, the fortunes of the Catholic Church did not improve, since "the Uganda People's Congress (UPC) which led the country into independence was generally Protestant." 22 In the play, it is implied that Wamala belongs to the triumphant party that comes to power at independence, in this case the Protestants, but in order to win acceptance among the Catholics, he marries Tinka, whose father is a prominent Catholic chief.

That Wamala's sexual relations with Tinka is a performance of his political masculinity is made clear by the way he gloats over snatching her from the Catholic Church, with its leadership of priests and mother superiors looking on, helplessly. This explains why he does unspeakable things, for instance openly wooing her while her colleagues prayed in the convent, singing "Ave Maria," ${ }^{23}$ and sleeping with her in open spaces as the passage below highlights:

TINKA: I broke my vow.

WAMALA: By the doorstep of the chapel ... on the cold cement?

TINKA: While the stars spied on us.

WAMALA: Then in the cemetery too ... down the valley.

TINKA: You said it was safe.

WAMALA: And so it was.

TINKA: Except for the holy ghosts weeping ... turning away, ashamed.

WAMALA: Guilty now, are you? Rather late in the day.

21 Bengt Sundkler and Christopher Steed. A History of the Church in Africa (Cambridge: Cambridge University Press, 2004), 1010.

22 Mujaju, "The Political Crisis," 68.

23 Ruganda, The Burdens, 37-38. 
From a Habit to a Husband: Representation of the Intersection between Religion and Masculinities in John Ruganda's Play, The Burdens (1972)

TINKA: We didn't have to defile the holy grounds.

WAMALA: Soft moans waking up the dead. I liked it. Every ticking second of it.

TINKA: The things you made me do! ${ }^{24}$

Were Wamala an ordinary mortal, it is certain that the priests and the superiors of the convent would have challenged his inappropriate goingson with Tinka, but because he is a powerful man - a minister in a government that they had demonized shortly before independence - they turn a blind eye to his actions, in order to avoid further antagonizing him and his colleagues. In other words, they adopt what Patrick M. Boyle calls a "self-protective" stance. ${ }^{25}$ This is, unfortunately, at the expense of the cardinal principles governing the Catholic Church, for instance the requirement that the nuns live a chaste life. Wamala's unfettered access to Tinka's convent, and therefore to her body, both of which are imagined in the play as porous, should therefore be read as an act of humiliation of the Catholic Church and a performance of what I would like to call vengeful, vindictive masculinity. This is a masculinity that is not aimed at doing something noble, say participating in "development projects which will raise the standards of living of the people, and give more meaning and dignity to human life," but one that aims at showing the Church leaders that he, Wamala, can do whatever he feels like with impunity, even if it means raiding the Catholic convent for a wife. ${ }^{26}$ Suffice it to mention that having sexual intercourse in the cemetery can be read at a symbolic level, for the love between Wamala and Tinka ends up in the cemetery when the latter murders the former at the end of the play.

It is a mark of Tinka's fortitude that despite Wamala's dehumanizing action of turning her into a revenge weapon, she does not lapse into self-pity. Instead, she asserts her position as his wife early on, and kicks out his

\footnotetext{
24 Ruganda, The Burdens, 38.

25 Patrick M. Boyle, "Beyond Self-Protection to Prophecy: The Catholic Church and Political Change in Zaire," Africa Today 39, no.3 (1992): 51.

26 Trevor Huddleston, "The Christian Churches in Independent Africa," African Affairs 68, no. 270 (1969): 48.
} 
The African Journal of Gender and Religion Vol. 26 No 1 (2020)

friends and family members, when she realises that they will make her life hard. Even when he becomes destitute later on, she still desires him sexually, and reprimands him for having affairs with other women that she contemptuously calls "tarts". ${ }^{27}$ In one sassy passage, she openly asks him for sex:

TINKA: Let's go to bed.

WAMALA: What time is it?

TINKA: About two, I think.

WAMALA: I will have another shot. And off to bed. (Fills his glass)

TINKA: You said it's the only thing that works.

WAMALA: The drink?

TINKA: No. You know ... the other thing.

WAMALA: Oh, the only thing that works these days. ${ }^{28}$

Here, Tinka subverts Wamala's vengeance in a remarkable way by insisting on her conjugal rights, moreover without caring about what he reveals as his motivation to court and marry her. This has the effect, I suggest, of making Wamala's project not just frivolous and ridiculous, but also ineffectual as it does not deter her from having him when she wants to. Besides, by taking care of her sexual desires without fixating herself on Wamala's vengeance, she frees herself from the object or weapon that he turned her into and becomes a subject with a will of her own - a protagonist who is able to feed her children when their father is busy drinking in order to "drug" himself "against depression and frustration." 29 In the next subsection, I delve deeper into the ways in which Tinka asserts her selfhood

\footnotetext{
27 Ruganda, The Burdens, 10.

28 Ruganda, The Burdens, 44.

29 Ruganda, The Burdens, 25.
} 
From a Habit to a Husband: Representation of the Intersection between Religion and Masculinities in John Ruganda's Play, The Burdens (1972)

even more pronouncedly in an environment wherein Wamala becomes increasingly abusive of her, both verbally and physically.

\section{Performing Feminine Power in an Abusive Marriage: Tinka's Challenge to Wamala's Violent Masculinity}

When Wamala falls from grace, he descends into alcoholism and destitution, which make it impossible for him to perform his duties as the man of the house, like providing food for his family. Tinka takes up this role, thereby becoming "the husband of the household," as the playwright puts it in his introduction to the play. ${ }^{30}$ She pays school fees for Kaija and poll tax for her husband, bringing to mind Roni Strier's observation that

To be a mother in poverty means to take care of everything. You don't have help. You have to look for ways to get to the end of the month with the money you don't have. You have to cook, look after the children in school, help them with homework, take them to the doctor ... ${ }^{31}$

Instead of appreciating Tinka for taking on all this work, Wamala instead tortures her in an attempt to make her submissive to him. Abasi Kiyimba's view that in Buganda "a woman may be beaten to enforce compliance" 32 since "a 'real man' must demand the obedience of his wife, even if this means beating her," helps us to understand Wamala's actions here. ${ }^{33}$ Indeed, after he hurts Tinka as he wrenches a bottle of illicit gin from her, he asks her to be respectful to him, poor though he is:

A man always wants a little bit of respect. Just a little bit, you know. To make him feel he is the boss in his own house, not a door-mat for every bastard to wipe his shoes

30 Ruganda, The Burdens, vi.

31 Roni Strier, "Gendered Realities of Poverty: Men and Women's Views of Poverty in Jerusalem," Social Service Review 79, no.2 (2005): 355.

32 Abasi Kiyimba, "Men and Power: Masculinity in the Folktales and Proverbs of the Baganda," in Masculinities in African Literary and Cultural Texts, eds. Helen Nabasuta Mugambi and Tuzyline Jita Allan (Oxfordshire: Ayebia Clarke Publishing Limited, 2010), 41.

33 Kiyimba, "Men and Power," 42. 
on. You shouldn't tread on a man like that, poverty or no poverty [...] The world outside is hell let loose. It's ruthless. It breaks one. Everyone orders you to walk with your tail limp between your thighs. They don't want you to raise your head. They want you to know that your life is in their hands [...] They can break it like a stick, if they choose to. And they always do, because it gives them the feel of power. They want you to know they are now on top, sitting on your head. And you beneath their buttocks, suffocating. So when a man comes home from this hell, this crowd full of power-hungry bastards with twitching hands - hands eager to grab and get rich, get rich quickly - a man wants sympathy and sweetness, tender care and kindness. Not silent curses. ${ }^{34}$

This passage re-confirms that The Burdens is heavily invested in masculinity as an identity. The order of things in the newly independent African country where this play is set is that those people who are in power and are rich are the men; those who are poor and do not occupy political office are weak and vulnerable, hence the powerful simile of their lives being like a stick that can be broken. Besides, these poor people are treated with contempt, hence the metaphor of the doormat that people wipe their shoes on, and that of the rich and powerful people sitting on their heads. In other words, the rich and powerful practice a masculinity that is destructive of the poor, as it dehumanizes them, thereby emptying them of value and respect.

The passage also makes it clear that poor people like Wamala are struggling against institutionalized poverty, where a few get-rich-quickly people are amassing wealth to the detriment of the majority, hence the numerous kondos (robbers) prowling in the night. Wamala tries to reach out to the President to personally apologize to him and ask for a job, but the many people surrounding him, including neo-colonial agents who work with and for the Presidency, frustrate Wamala's efforts. His experience as a former Grade III teacher, a former Principal of a Teachers' Teaching

34 Ruganda, The Burdens, 34-35. 
From a Habit to a Husband: Representation of the Intersection between Religion and Masculinities in John Ruganda's Play, The Burdens (1972)

College, and a former Minister of Local Government is adequate to get him a job in the newly independent country where few people are welleducated, but the bigwigs who decide who gets employed and who remains unemployed have blacklisted him because of his aborted attempt to overthrow the government, thereby leading to his impoverishment. His destitution can therefore be considered the work of what Hans Husum and Odd Edvardse call "the poverty machine" which they describe as a "welltrimmed and well-managed politico-social system in action, reproducing conditions of poverty". ${ }^{35}$

It is this impoverishment that makes Tinka ridicule Wamala. By telling her son, Kaija, that Wamala "has never been up [...] As high up as men like Isaza, or Isimbwa," Tinka is emptying Wamala of the respect the boy has for him, thereby opening him up to the child's contempt and ridicule. ${ }^{36}$ Kaija realizes that his mother is a little too hard on Wamala, and curtly responds, "He doesn't have to have been up enough to be my father, I suppose." ${ }^{37}$ Had Tinka held the same attitude - that Wamala does not have to be rich to deserve her respect as a husband - it is possible that he would not have felt as worthless as he does to the extent of telling her that a man needs "sympathy and sweetness, tender care and kindness." Had Tinka perceived her role of caring for her family in Christian terms since "[f]eeding others is inherently sacramental", it is possible that she would have heeded Wamala's plea. ${ }^{38}$ But she does not; instead she belittles every effort Wamala makes to lift himself out of poverty. For instance when he fancies that he can make a living out of composing slogans like "VOTE VALOUR; VOTE VALUE; VOTE VINCENT," 39 Tinka punctures his enthusiasm by correctly (albeit coldly) pointing out that every slogan can be manipulated to communicate an opposite message, so much so that the one he

35 Hans Husum and Odd Edvardse, "Poverty as Trauma: Methodological Problems When Reality Gets Ugly," In Disability and Poverty: A Global Challenge, ed. Arne H. Eide and Benedicte Ingstad (Bristol: Bristol University Press, 2011), 214.

36 Ruganda, The Burdens, 6.

37 Ruganda, The Burdens, 6.

38 Eliza Jane Getman, "'Extending the Table': Eucharist as a Model for Feminist Food Justice," Journal of Gender and Religion in Africa 23, no.2 (2017): 27.

39 Ruganda, The Burdens, 30. 
composed for Kanagonago at a fee could ultimately be distorted to "VOTE VAPOUR; VOTE VIOLENCE; VOTE VENGEANCE; VOTE VINCENT." 40

Even when Wamala tries his level best to support his family as illustrated by his purchase of a second-hand bed, the response he gets from Tinka is brutal, for she tells him that the family is tired of second-hand things and that there are homes that have never known second-hand things. His response to her criticism - that there are homes which cannot even afford ten-hand things - is a call to her to be grateful for his humble gesture of responsibility as a father and husband. Perhaps Francis Imbuga is correct when he observes:

The real cause of tension in the Wamala family is Tinka's disrespect for her husband because of his inability to contribute to the family kitty due to his lack of a job. Even when Wamala manages to contribute a little something, as is the case with the bed he buys for Kaija, Tinka still despises him and subjects him to extreme ridicule. ${ }^{41}$

For Wamala, poverty becomes what Roni Strier calls "an extremely painful and negative emotional experience" 42 that leads to "shame and stigma," 43 for it results in "the psychological attrition of men" since it destroys their dignity in a society which is "strongly stratified in terms of class and gender," thereby indicating "the fragile nature of masculinity as a socially constructed and achieved status." 44 Informed by Timothy Nonn's paper entitled "Hitting Bottom: Homelessness, Poverty, and Masculinity," Strier makes an observation that rings true for Wamala's situation in The Burdens:

Poverty threatens some of the basic attributes used to measure a successful masculinity. For these men, poverty

\footnotetext{
$40 \quad$ Ruganda, The Burdens, 31.

41 Francis Davis Imbuga, "Thematic Trends and Circumstance in John Ruganda's Drama" (PhD Diss., University of lowa, 1991), 132.

42 Strier, "Gendered Realities," 354.

43 Strier, "Gendered Realities," 354-355.

44 Strier, "Gendered Realities," 356.
} 
represents a call to come to terms with their emasculation and a challenge to address their denigrated masculinities as a way to regain a sense of pride. The masculine self in poverty is an unrecognizable self. Bound within the accepted canons of gender, a life in poverty leads to a devastated masculinity. While class constraints reduce the scope of life options considerably, gender decreases the number of acceptable roles men are allowed to display. Therefore, men living in poverty have to search for versatile views of masculinity or to perish in terms of accepted gender conventions. ${ }^{45}$

To repair his sense of manliness, Wamala decides to spend most of his time in the bar, for as Margrethe Silberschmidt's research among the Kisii people of Kenya indicates, men who are humiliated by their wives find recourse in bars "officially to socialize with peers" and meet up with other women who repair their hurt ego by making them "feel important." 46 If declaring a man impotent is "the ultimate act of contempt a woman could commit against a husband in Buganda society" as Helen Nabasuta Mugambi avers, ${ }^{47}$ then we can read Wamala's goings-on with other women as an attempt at asserting his virility as a way of reclaiming his depleted political and economic power. He is penniless and politically insignificant, it is true, but he is not completely burnt-out as a man for he has women who find him a real man in bed.

It is significant that in the play the fight that culminates in the murder of Wamala has to do with the fact that he has other women, coupled with Tinka's view that he is a worthless man, as the passage below illustrates:

TINKA: He said I was a good-for-nothing bitch.

45 Strier, "Gendered Realities," 356.

46 Margrethe Silberschmidt, "Disempowerment of Men in Rural and Urban East Africa: Implications for Male Identity and Sexual Behaviour," World Development 29, no.4 (2001): 666.

47 Helen Nabasuta Mugambi, "Masculinity on Trial: Gender Anxiety in African Song Performances," in Masculinities in African Literary and Cultural Texts, eds. Helen Nabasuta Mugambi and Tuzyline Jita Allan (Oxfordshire: Ayebia Clarke Publishing Limited, 2010), 84. 
The African Journal of Gender and Religion Vol. 26 No 1 (2020)

KAIJA: And you said he was a lousy skunk.

TINKA: He had other women who knew how.

KAIJA: Women who could satisfy him better than you.

TINKA: Don't ever repeat that, Kaija.

KAIJA: I listen to it every day.

TINKA: Then out of anger I told him that he didn't have to worry because I'd prefer a dog to him, in future.

KAIJA: Mooother!

TINKA: I said it out of anger. Then he started hitting me. He kept slapping me. I didn't even protest because I knew he was right. But when he went to sleep and I had time to think it over, I realized I'd been right. So I stormed in ... and it happened. ${ }^{48}$

What Tinka euphemistically refers to here as the thing that "happened" is her murder of Wamala. His provocative statement that there are other women who are better in bed than her costs him his life, as Tinka decides to silence him forever. One of the pertinent questions about her killing of Wamala is whether it is manslaughter (done upon provocation or in selfdefence) or murder (premeditated before execution). Tinka's plea to her children after killing their father - "You'll understand when you grow up. It was not my fault, God is my witness. I tried to put up with so many terrible things. Things you will never know [...] It is not my fault. Nobody will blame me when they come to know" - indicates that it was manslaughter, since the notion of putting up with so many things implies that she was provoked into the act after a long period of time. ${ }^{49}$ This view is in line with P. D. Chimbos' observation that "inter-spouse homicide [...] is rarely a sudden

48 Ruganda, The Burdens, 73.

49 Ruganda, The Burdens, 79. 
From a Habit to a Husband: Representation of the Intersection between Religion and Masculinities in John Ruganda's Play, The Burdens (1972)

explosion in a blissful marriage" but is rather an end point of an ongoing series of bitter quarrels between parties. ${ }^{50}$

If it is true that "[w]omen [who kill their partners] tend to be judged against the notion of the ideal woman, who is passive, and certainly does not kill her partner, and therefore not only contravenes the law but also societal norms whereas men are judged solely against the legal requirements, elicit sympathy from the judiciary and correspond to acceptable notions of masculine aggression" as Anna Carline argues, then Ruganda's depiction of the killing of Wamala should be applauded, as it does not follow this stereotypical pattern. ${ }^{51}$ Instead, Ruganda motivates the action from the logic of the abusive relationship the couple has been having. While the audience may not approve of Tinka's decision to do away with Wamala, at the same time they appreciate his contribution to the fate that befalls him, since they do not condone his constant assaults against her.

By giving Tinka the agency to protest against the wrongs committed against her, Ruganda constructs her as a character who is in control of herself and her destiny, somebody who will not tolerate abuse from a man even if it means serving time in prison. By framing her act of homicide as rational, Ruganda debunks the tendency to stereotype women as loving, peaceful, conciliatory, and therefore mere victims of abuse (Easteal et a). ${ }^{52}$ Tinka's killing of Wamala is one instance that relates to the title of Sylvia Tamale's book on gender and parliamentary politics in Uganda When Hens Begin to Crow - in the sense that a woman, who is usually stereotyped as peace-loving, ends up committing homicide as a means of asserting her subjectivity. ${ }^{53}$ Kaija's statement - that Tinka and Wamala "were fighting away like tigers" - shows that she was not passively receiving a beating, but defending herself quite impressively, to the extent

50 Cited in Lilian Tibatemwa-Ekirikubinza, Women's Violent Crime in Uganda: More Sinned Against than Sinning? (Kampala: Fountain Publishers Limited, 1999), 50-51.

51 Anna Carline, "Women who Kill their Abusive Partners: From Sameness to Gender Construction," Liverpool Law Review 26 (2005): 23.

52 Patricia Easteal, Lorana Bartels, Noni Nelson, and Kate Holland, "How are Women who Kill Portrayed in Newspaper Media? Connections with Social Values and the Legal system," Women's Studies International Forum 51 (2015): 33.

53 Sylvia Tamale, When Hens Begin to Crow: Gender and Parliamentary Politics in Uganda (Kampala: Fountain Publishers, 1999). 
that in the eyes of the young man, the two seemed of equal strength, hence the simile he uses. ${ }^{54}$ One could argue, of course, that Tinka's impressive performance is relative to Wamala being drunk, but the issue to emphasize here is that she refuses to passively receive beatings. Instead, she defends herself. If in Africa, a woman becomes a possession in marriage, "voiceless and often rightless in her husband's family except, in some groups, through what accrues to her through children" as Molara Ogundipe-Leslie (cited in Da Silva) ${ }^{55}$ argues, in The Burdens this is not the case. Tinka does not accept Wamala's assertion that he is the head of the house; she challenges him to show this headship in action, for instance by paying fees for Kaija and taking Nyakake (who has a terrible cough) to a proper medical facility.

That The Burdens gives us a clear context within which Tinka kills Wamala is an indication that literary texts can contribute to a more nuanced understanding of spousal homicides. Ruganda demonstrates that what Easteal et al expect of the media (newspapers, for instance) in helping the public to understand the circumstances in which and the reasons why homicides occur, "including the societal factors which may precipitate this," can best be done through a well-thought out play like the one we are discussing. ${ }^{56}$ By dramatizing the conflict with a nuanced interpretation of the difficult socio-economic difficulties precipitating it, The Burdens steers clear of simplifying Tinka's murder of Wamala, but instead makes it a complex issue that continues to provoke debate forty eight years after it was published. Jessica Wahman is right to observe that

When watching a play, we vicariously experience the lives of actual people who are embroiled in their situations and are trying to express their points of view [...] The actor on stage in front of us is to convince us, through a variety of well-crafted somatic tools, that she or he really is undergoing the elation, torment, perplexity, reflection, and so on that we see before us. Because of this, we take up

\footnotetext{
54 Ruganda, The Burdens, 71.

55 Meyre Ivone da Silva, "African Feminists towards the Politics of Empowerment," Revista de Letras 44, no.2 (2004): 134.

56 Easteal, et al, "How are Women," 40.
} 
the character's experiences as actually undergone and experience any stated theoretical position as actually embedded in a context that comes readymade with interests, problems, desires, sometimes animosities, and practical implications. Furthermore, if the play is working, we identify, to some extent, with even the most unsavory characters and both sympathize with and understand something about their condition. As such, we hopefully learn something that we did not grasp before about the way matters look to someone who views the world very differently than we might. ${ }^{57}$

One of the things that make it possible for drama to communicate this powerfully, is what Patrick Verriour calls its reflective power, that is to say, its capacity to examine "human issues and behavior in specific social contexts." ${ }^{58}$ The other is drama's capacity to provoke the person reading it on the page or watching it on stage to ask questions about what is happening - why particular characters are saying what they are saying or doing what they are doing; what each character's background or history is that informs their words and actions; the implications of what they are saying or doing; the fairness of what happens to each of them; and so forth. This dialogic engagement between the playwright or theatre director and the audience, on the one hand, and the characters on the page or stage and the audience on the other, opens up a space for debate, for instance on the fairness of what happens to the characters, or the fairness with which the playwright or the director has rendered certain characters. This debate enriches the play in the sense that it brings to the table different viewpoints on the work, which makes it richer in voicing particular issues, besides giving the readers or theatre-goers agency in the sense that they can pass informed judgments on the success or failure of the play.

\footnotetext{
57 Jessica Wahman, "Drama as Philosophical Genre," The Journal of Speculative Philosophy 28, no. (2014): 458.

58 Patrick Verriour, "The Reflective Power of Drama," Language Arts 61, no.2 (984): 125.
} 


\section{The Pressures of Growing Up in a Troubled Home: Kaija's Incipient Masculinity}

The play makes it clear that the gender-based violence in Wamala's family affects his son, Kaija, in a negative way. Besides having terrible nightmares in which he sees a flood of blood, he uproots a widow's cotton crop, because to him, she has no business working diligently while his parents fight like tigers. ${ }^{59}$ When an age-mate, Tibasiga, reprimands him for doing this dastardly deed and threatens to report him to his mother, he beats her up and breaks her pot. The link between his actions and the incipient masculinity at stake here is made evident when he decides to piss in a swimming pool, this being his way of defying decorum and propriety, since he is aware that swimming pools are recreation facilities, not urinals. But it also points to his revolt against the opulence that the swimming pool represents: just like he says the widow did not have the right to go about her work as if the fighting between his parents was normal, in his view the people who own or patronize the swimming pool have no business having such an expensive facility, as the majority of the population wallow in extreme poverty in the slums.

To deal with these pressures of living in a troubled home, Kaija finds recourse in the world of orature, through the folktales his mother tells him. One of the stories he loves and which he implores his mother to tell him again, is how Ngoma's only daughter, Nyenje, ended up marrying a leper. In this tale, the octogenarian paramount chief gambles with the future happiness of his only child, Nyenje, by proclaiming that "whoever wanted her beautiful hand had to prove his prowess by climbing a very tall tree and bringing down, in one piece, the gourd containing her umbilical cord."60 Chiefs, princes, hunters and herdsmen try their luck, but fail to bring down the gourd. To the surprise of everybody, a "common leper stinking with leprosy and commonness" and "[d]ragging misery behind him" joins the challenge, and as people laugh at him (since they expect him to fail the challenge on account of his disease), he sings a love song to Nyenje, until he reaches the gourd and brings it down. ${ }^{61}$ Ngoma regrets his

\footnotetext{
59 Ruganda, The Burdens, 73.

60 Ruganda, The Burdens, 15-16.

61 Ruganda, The Burdens, 16.
} 
From a Habit to a Husband: Representation of the Intersection between Religion and Masculinities in John Ruganda's Play, The Burdens (1972)

proclamation, but can do nothing, since as a chief he cannot dishonour his own word without attracting the accusation that he is a deceitful leader.

Several issues on gender relations are highlighted in this tale. In the first place, it is told by Tinka, who learnt it from her mother, pointing to the role of women as literary creators and preservers of beautiful works which are meant to entertain and instruct. Tinka emphasizes the instructive role of the tale when she says, "A stubborn memory still lingers in the minds of a few. The few old ones whose duty it is to think and hide relevancies in irrelevancies and share their uneasiness before graves overtake them."62 The tale therefore positions her, and her mother before her, as not just entertainers, but also as the philosophers and educators of the community, if we accept Okot p'Bitek's view that "a thought system of a people is created by the most powerful, sensitive, and imaginative minds that that society has produced [...] the few men and women, the supreme artists, the imaginative creators of their time, who form the consciousness of their time" and who "respond deeply and intuitively to what is happening, what has happened and what will happen" by making the laws that govern society, which they express "through metaphor and symbol, in image and fable", thereby luring their subjects by the sweetness of their songs and the beauty of their works. ${ }^{63}$

The tale also highlights the fact that the society in which it is set is patrilineal, as shown by the emphasis on the fact that Ngoma did not have a son, but only a daughter, and yet he was eighty-five years old. We are not told anything about Nyenje's mother. Perhaps she is dead, or perhaps in this society, decisions regarding the marriage of daughters are made by fathers, without any consultation with the mother, or other female relatives, for that matter. But most importantly, the tale depicts the father gambling with his daughter's life and happiness, deciding on a challenge that has the potential to land her in the hands of any person who is able to climb a tall tree, that is to say, anybody who is brave, irrespective of other factors that matter in marriage. It is my view that the playwright condemns this reckless behaviour of the Chief's, as it ruins the daughter's future by giving her

62 Ruganda, The Burdens, 15.

63 Okot p'Bitek, Artist the Ruler: Essays on Art, Culture and Values (Nairobi: East African Educational Publishers Ltd., 1986), 39. 
away in marriage to a man she does not love; a man the entire village despises; a man who is likely to infect her with leprosy.

\section{Conclusion}

It is my contention that by portraying Tinka as begrudging her role as carer and sole provider for the family, Ruganda loses the opportunity to communicate a gender-sensitive message - that women can do amazing work in heading families, whether or not their husbands give a hand. Besides, it robs Tinka of the possibility of looking at her present circumstances in terms of her background as a formerly religious woman, that is to say, as a person with a pastoral mission to her children and her fallen husband, following Getman's view, already cited above, that the act of providing for one's family is a powerful expression of loving and serving God. ${ }^{64}$

While it is possible to liken her killing of Wamala to Firdaus' killing of her pimp in Nawal El Sadaawi's Woman at Point Zero in the sense that Firdaus, like Tinka, "protects herself by attacking the person who is doing her harm," thereby taking on "a violently masculine position, refusing the female-nuanced role of victim," Tinka is, unlike Firdaus, apologetic about what she has done. ${ }^{65}$ The rhetorical question she asks, "Oh my God. What have I done. What have I done?" 66 points to her penitent heart and her plea that God forgive her the sin she has committed.

Finally, this paper has demonstrated that drama is a powerful medium through which pertinent issues affecting society are reflected upon. Using Ruganda's play, The Burdens, which was published forty-eight years ago, it has examined the representation of religion and masculinity in this text, with special focus on the circumstances under which a Catholic nun leaves the convent to get married, and how a former minister in the government becomes impoverished. It has highlighted the fact that masculinity as an

\footnotetext{
64 Getman, “'Extending the Table'”, 27.

65 Marilyn Sluttzky Zucker, "Killing the Pimp: Firdaus's Challenge to Masculine Authority in Nawal El Sadaawi's Woman at Point Zero," in Masculinities in African Literary and Cultural Texts, eds. Helen Nabasuta Mugambi and Tuzyline Jita Allan (Oxfordshire: Ayebia Clarke Publishing Limited, 2010), 247.

66 Ruganda, The Burdens, 80.
} 
From a Habit to a Husband: Representation of the Intersection between Religion and Masculinities in John Ruganda's Play, The Burdens (1972)

identity is not cast in stone, for a man's fortunes can change for the worse, thereby leading to what Margrethe Silberschmidt calls "a shift in the balance of power between the genders". ${ }^{67}$ If in African popular culture, masculinities are "perpetually on trial" as Mugambi asserts, ${ }^{68}$ the same is true in African literature, as I have demonstrated in this paper.

67 Margrethe Silberschmidt, "Have Men Become the Weaker Sex? Changing Life Situations in Kisii District, Kenya," The Journal of Modern African Studies 30, no.2 (1992): 251.

68 Mugambi, "Masculinity on Trial", 94. 


\section{References}

Boyle, Patrick M. "Beyond Self-Protection to Prophecy: The Catholic Church and Political Change in Zaire." Africa Today 39, no.3 (1992): 49-66.

Butler, Judith. Gender Trouble: Feminism and the Subversion of Identity $2^{\text {nd }}$ Edition. London and New York: Routledge, 1999. [1990]

Carline, Anna. "Women who Kill their Abusive Partners: From Sameness to Gender Construction." Liverpool Law Review 26 (2005): 13-44.

Da Silva, Meyre Ivone. "African Feminists towards the Politics of Empowerment." Revista de Letras 44, no.2 (2004): 129-138.

Easteal, Patricia, Lorana Bartels, Noni Nelson, and Kate Holland. "How are Women who Kill Portrayed in Newspaper Media? Connections with Social Values and the Legal system." Women's Studies International Forum 51 (2015): 31-41.

Getman, Eliza Jane. "'Extending the Table': Eucharist as a Model for Feminist Food Justice." Journal of Gender and Religion in Africa 23, no.2 (2017): 24-42.

Gikandi, Simon and Evan Mwangi. The Columbia Guide to East African Literature in English Since 1945. New York: Columbia University Press, 2007.

Hills, Helen. "The Veiled Body: Within the Folds of Early Modern Neapolitan Convent Architecture." Oxford Art Journal 27, no.3 (2004): 271290.

Huddleston, Trevor. "The Christian Churches in Independent Africa." African Affairs 68, no.270 (1969): 42-48.

Husum, Hans and Odd Edvardsen. "Poverty as Trauma: Methodological Problems When Reality Gets Ugly." In Disability and Poverty: A Global Challenge, edited by Arne $\mathrm{H}$. Eide and Benedicte Ingstad, 207-223. Bristol: Bristol University Press, 2011. 
From a Habit to a Husband: Representation of the Intersection between Religion and Masculinities in John Ruganda's Play, The Burdens (1972)

Kiyimba, Abasi. "Men and Power: Masculinity in the Folktales and Proverbs of the Baganda." In Masculinities in African Literary and Cultural Texts, edited by Helen Nabasuta Mugambi and Tuzyline Jita Allan, 35-49. Oxfordshire: Ayebia Clarke Publishing Limited, 2010.

Imbuga, Francis Davis. "Thematic Trends and Circumstance in John Ruganda's Drama." PhD diss., University of lowa, 1991.

Imbuga, Francis Davis. "An Introduction to John Ruganda, the Playwright." In Uganda: The Cultural Landscape, edited by Eckhard Breitinger, 250261. Kampala: Fountain Publishers, 2000.

Mugambi, Helen Nabasuta. "Masculinity on Trial: Gender Anxiety in African Song Performances." In Masculinities in African Literary and Cultural Texts, edited by Helen Nabasuta Mugambi and Tuzyline Jita Allan, 78-94. Oxfordshire: Ayebia Clarke Publishing Limited, 2010.

Mujaju, Akiiki B. "The Political Crisis of Church Institutions in Uganda." African Affairs 75, no.298 (1976): 67-85.

Nazareth, Peter. "The Social Responsibility of the East African Writer." Callaloo 8/10 (1980): 87-105.

Ojaide, Tanure. "Deploying Masculinity in African Oral Poetic Performance: The Man in Udje." In Masculinities in African Literary and Cultural Texts, edited by Helen Nabasuta Mugambi and Tuzyline Jita Allan, 66-77. Oxfordshire: Ayebia Clarke Publishing Limited, 2010.

p'Bitek, Okot. Artist the Ruler: Essays on Art, Culture and Values. Nairobi: East African Educational Publishers Ltd., 1986.

Ruganda, John. The Burdens. Nairobi: Oxford University Press, 1972.

Salih, Sara. Judith Butler. London and New York: Routledge, 2002.

Schulz, Dorothea and Marloes Janson. "Introduction: Religion and Masculinities in Africa." Journal of Religion in Africa 46, no.2/3 (2016): 121128. 
The African Journal of Gender and Religion Vol. 26 No 1 (2020)

Silberschmidt, Margrethe. "Have Men Become the Weaker Sex? Changing Life Situations in Kisii District, Kenya." The Journal of Modern African Studies 30, no.2 (1992): 237-253.

Silberschmidt, Margrethe. "Disempowerment of Men in Rural and Urban East Africa: Implications for Male Identity and Sexual Behaviour." World Development 29, no.4 (2001): 657-671.

Sundkler, Bengt and Christopher Steed. A History of the Church in Africa. Cambridge: Cambridge University Press, 2004.

Strier, Roni. "Gendered Realities of Poverty: Men and Women's Views of Poverty in Jerusalem." Social Service Review 79, no.2 (2005): 344-367.

Tamale, Sylvia. When Hens Begin to Crow: Gender and Parliamentary Politics in Uganda. Kampala: Fountain Publishers, 1999.

Tibatemwa-Ekirikubinza, Lilian. Women's Violent Crime in Uganda: More Sinned Against than Sinning? Kampala: Fountain Publishers Limited, 1999.

Verriour, Patrick. "The Reflective Power of Drama." Language Arts 61, no.2 (1984): 125-130.

Wahman, Jessica. "Drama as Philosophical Genre." The Journal of Speculative Philosophy 28, no. 4 (2014): 454-471.

Wasike, Chris J. C. "Feminization of the Ugandan nation in John Ruganda's The Floods, The Burdens and Black Mamba." Postcolonial Text 5, no.3 (2009): 1-15.

Zucker, Marilyn Sluttzky. "Killing the Pimp: Firdaus's Challenge to Masculine Authority in Nawal El Sadaawi's Woman at Point Zero." In Masculinities in African Literary and Cultural Texts, edited by Helen Nabasuta Mugambi and Tuzyline Jita Allan, 237-249. Oxfordshire: Ayebia Clarke Publishing Limited, 2010. 